\title{
Tanggungjawab Pemerintah Daerah terhadap kerusakan Terumbu Karang Di Kabupaten Raja Ampat
}

\author{
Muharuddin Muharuddin ${ }^{1}$, Wahab Aznul Hidaya ${ }^{2,}$ Jamaluddin Rumatiga $^{3}$ \\ Ilmu Hukum, Universitas Muhammadiyah Sorong \\ Email : amuharuddin@gmail.com ${ }^{1}$,wahabaznulhidaya@gmail.com ${ }^{2}$, \\ jamaluddin210@gmail.com ${ }^{3}$
}

\begin{abstract}
This study aims to determine the responsibilities of local governments in solving coral reef damage, and to find out the process of resolving coral reef damage to the Raja Ampat Regency Government. The research carried out in the Raja Ampat Regency government uses empirical juridical research type, and by making in depth observations about the symptoms studied. Besides structured interviews with these respondents, the researcher also conducted free interviews with certain communities domiciled in Raja Ampat Regency with different locations, so that researchers can examine the rationality and accuracy of local government responsibility for coral reefs in Raja Ampat district. Analysis. The findings obtained from this study are, That the responsibility of the local government of Raja Ampat Regency is in solving damage to coral reefs, that is request compensation for damage to coral reefs carried out by the Cruise Boat MV Kaledonian Sky from the United Kingdom covering an area of 1,600 M2 on Mios Mansuar Island which is as much Rp. 6,000,000,000,000 (six trillion rupiah), which was delivered directly by the Raja Ampat Regency government to the British Embassy in Indonesia, and replanting coral reefs on Mios Mansuar Island.
\end{abstract}

Keywords: Local Government Responsibility, Coral Reef Damage, Raja Ampat Regency, Law Number 32 of 2009, Law Number 45 of 2009.

\begin{abstract}
Abstrak
Penelitian ini bertujuan untuk mengetahui Tanggungjawab Pemerintah Daerah dalam penyelesaiankerusakan terumbu karang, dan untuk mengetahui proses penyelesaian terhadap kerusakan terumbu karang pada Pemerintah Daerah Kabupaten Raja Ampat. Peneltian yang dilakukan di pemerintah Kabupaten Raja Ampat ini menggunakan jenis penelitian yuridis empiris, dan dengan melakukan pengamatan secara mendalam mengenai gejala yang diteliti. Di samping wawancara terstruktur dengan responden tersebut, peneliti juga melakukan wawancara bebas dengan masyarakat tertentu yang berdomisili di Kabupaten Raja Ampat dengan lokasi yang berbeda-beda, sehingga peneliti dapat menelaah rasionalitas dan akurasi tanggungjawab pemerintah daerah terhadap terumbu karang di kabupaten Raja Ampat. Analisa data peniliti lakukan dengan mengunakan analisis kualitatif. Temuan yang di peroleh dari penelitian ini adalah: (1) Bahwa Tanggung jawab pemerintah daerah Kabupaten Raja Ampat dalam penyelesaian kerusakan terumbu karang, yaitu meminta ganti rugi atas kerusakan terumbu karang yang dilakukan oleh Kapal Pesiar MV Kaledonian Sky asal Negara Inggris seluas 1.600 M2 di Pulau Mios Mansuar yakni sebanyak Rp. 6.000.000.000.000 (enam trilyun rupiah), yang disampaikan langsung oleh pemerintah Kabupaten Raja Ampat kepada Kedutaan Besar Inggris di Indonesia, dan melakukan penanaman ulang terumbu karang di Pulau Mios Mansuar.
\end{abstract}


Kata Kunci : Tanggungjawab Pemerintah Daerah, Kerusakan Terumbu Karang, Kabupaten Raja Ampat, Kajian Undang-Undang Nomor 32 Tahun 2009, dan UndangUndang Nomor 45 Tahun 2009.

\section{PENDAHULUAN}

Sebagai negara kepulauan terbesar dan secara geografis terletak di antara Samudera Pasifik dan Samudera Hindia, keanekaragaman hayati laut Indonesia tak tehitung jumlahnya. Terumbu karang Indonesia sangat beraneka ragam dan memegang peranan yang sangat penting dalam menjaga keseimbangan lingkungan dan menyumbangkan stabilitas fisik pada garis pantai tetangga sekitarnya. Oleh karena itu harus dilindungi dan dikembangkan secara terus menerus baik untuk kepentingan generasi sekarang maupun generasi mendatang. Terumbu karang sangat mudah terpengaruh oleh kondisi lingkungan sekitarnya baik secara fisik juga biologis. Akibat kombinasi dampak negatif langsung dan tidak langsung pada terumbu karang Indonesia, sebagian besar terumbu karang di wilayah Indonesia saat ini sudah mengalami kerusakan yang sangat parah. Bagaimanapun juga, tekanan terhadap keberadaan terumbu karang paling banyak diakibatkan oleh kegiatan manusia, sehingga perlu dilakukan langkahlangkah pencegahan. Peningkatan kegiatan manusia sepanjang garis pantai semakin memperparah kondisi terumbu karang. Oleh karena itu merupakan kebutuhan mendesak untuk menerapkan konservasi dan rencana-rencana pengelolaan yang baik untuk melindungi terumbu karang dari kerusakan yang semakin parah. Langkah dan kebijakan yang perlu dilakukan untuk mengurangi ancaman terhadap terumbu karang di Indonesia adalah dengan meningkatkan kesadaran masyarakat terhadap perlunya menjaga kelestarian terumbu karang dan meningkatkan keterlibatan semua pihak dalam menjaga kelestarian terumbu karang di Indonesia.

Salah satu faktor yang menentukan dalam pembangunaan adalah lingkungan hidup, dimana lingkungan hidup adalah tempat pembangunaan berlangsung. Lingkungan hidup mempunyai arti penting dalam kehidupan manusia, seperti tercantum dalam Undang-Undang Republik Indonesia Nomor 32 tahun 2009 tentang Pengelolaan dan Perlindungan Lingkungan Hidup, menyebutkan bahwa lingkuang hidup adalah kesatuan ruang dengan semua benda, daya, keadaan, dan makhluk hidup, termasuk manusia dan perilakunya yang mempengaruhi kelangsungan perikehidupan dan kesejahteraan manusia serta makhulk hidup lain. Ruang lingkup lingkungan hidup indonesia meliputi ruang, tempat Negera Kesatuan Republik Indonesia yang berwawasan nusantara dalam melaksanakan kedaulatan, hak berdaulat, dan 
yuridis. Dengan demikian, maka manusia seharusnya berusaha untuk menjaga terumbu karang yang ada tetap sehat dan serasi serta terpelihara, bahkan menjadikan terumbu karang yang ada menjadi lebih baik dan lebih indah.

Kerusakan yang sudah terjadi hendaknya diperbaiki sebelum menjadi bertambah parah. Salah satu upaya adalah membentuk peraturan yang baik dan lengkap, disertai penerapan dan penegakkan yang baik. Hal ini bertujuan untuk menjaga, memilihara lingkungan yang baik dan sehat, serta lestari. Dalam menerapkan dan menegakkan hukum lingkungan diperlukan pelaksana dan penegakkan hukum yang cakap, jujur, dan mengutamakan kepentingan umum daripada kepentingan diri dan golongan serta mementingkan masa depan daripada kenikmatan sesaat masa kini. Untuk itu dalam proses pembangunaan yang semakin berkembang dan berkelanjutan dianggap perlu suatu kajian mengenai dampak akan pembangunan itu sendiri seperti tercantum berdasarkan Undang-Undang Republik Indonesia Nomor 32 tahun 2009 tentang perlindungan dan pengelolaan lingkungan hidup, mnegaskan bahwa perusakkaan kekayaan alam, seperti terumbu karang, lahan gambut, dan hutan, merupakan tindakkan kriminal dengan pidana penjara.

Kepulauan Raja Ampat merupakan kawasan konservasi perairan yang telah ditetapkan oleh Keputusan Menteri Keluatan dan Perikanan Nomor 36/KEPMEN-KP/2014 tentang kawasan Konservasi Perairan Kepulauan Raja Ampat di Provonsi Papua Barat. Kendati telah di tetapkan dalam keputusan Menteri, namun tidak dapat dielakan bahwa kerusakan terumbu karang akibat dari aktivitas manusia dapat terjadi. Seperti halnya yang terjadi di Kabupaten Raja Ampat pada tanggal 4 Maret 2017, akibat dari peristiwa kandasnya kapal MV CALEDONIAN SKY diperairan pulau Mios Mansuar Kabupaten Raja Ampat mengakibatkan kerusakan terumbu karang yang diprediksikan seluas 1600 M2. Kerusakan kterumbu karang ini menjadi perhatian serius pemerintah Kabupaten Raja Ampat dan Pemerintah Republik Indonesia, sehingga untuk menindaklanjuti masalah tersebut, maka dilakukan berbagai langkah penyelesaian termasuk penanaman kembali terumbu karang yang rusdak tersebut. Bertolak dari latar belakang masalah yang penulis uraikan di atas, maka untuk mengkaji lebih dalam tentang bagaimana tanggungjawab pemerintah Kabupaten Raja Ampat dalam menyelesaikan permasalahan yang telah menjadi perhatian dunia ini, mengingat perairan Raja Ampat merupakan Harta Warisan Dunia yang dijaga kesinambungan ekosistem laut yang terkandung di dalamnya. Berangkat dari hal ini, maka penulis tertarik untuk mengkaji lebih dalam terkait hal tersebut.; (1) Bagaimana tanggungjawab pemerintah daerah Kabupaten Raja Ampat dalam 
penyelesain kerusakan terumbu karang? ; (2) Apa kendala dalam penyelesaian terhadap kerusakan terumbu karang di Kabupaten Raja Ampat?

Pengelolaan wisata bahari perlu aspek kehati-hatian karena pengelolaan pariwisata yang buruk, sering bertentangan dengan nilai estetika dan/atau daya dukung (carrying capacity)lingkungan pantai. Zhiyong dan Sheng (2009). Ancaman kerusakan terumbu karang disebabkan oleh 2 kategori utama yaitu yang berasal dari antropogenik dan alami. Kegiatan antropogenik peningkatan populasi masyarakat pesisir yang mengancam kesehatan terumbu karang, pembangunan pantai, overeksploitasi dan destructive fishing, serta polusi dan erosi lahan di daratan maupun di perairan. Souter dan Linden (2000).

\section{METODE PENELITIAN}

Peneltian yang dilakukan di pemerintah Kabupaten Raja Ampat ini menggunakan jenis penelitian yuridis empiris, dan dengan melakukan pengamatan secara mendalam mengenai gejala yang diteliti.

Di samping wawancara terstruktur dengan responden tersebut, peneliti juga melakukan wawancara bebas dengan masyarakat tertentu yang berdomisili di Kabupaten Raja Ampat dengan lokasi yang berbeda-beda, sehingga peneliti dapat menelaah rasionalitas dan akurasi tanggungjawab pemerintah daerah terhadap terumbu karang dikabupaten raja ampat. Analisa data peniliti lakukan dengan mengunakan analisis kualitatif.

Adapun penelitian ini mengunakan teknik analisa Data dengan mengelola Data hasil penelitian dan dianalisis secara kualitatif yaitu menganalisa data berdasarkan kualitasnya lalu dideskripsikan dengan menggunakan kata-kata sehingga diperoleh bahasa atau paparan dalam bentuk kalimat yang sistematis dan dapat dimengerti, kemudian ditarik kesimpulan.

\section{PEMBAHASAN}

Tanggungjawab Pemerintah Daerah Kabupaten Raja Ampat dalam Penyelesaian Kerusakan Terumbu Karang

Letak geografis Indonesia yang berupa kepulauan sangat berpengaruh terhadap mekanisme pemerintahan Negara Indonesia. Dengan keadaan geografis yang berupa kepulauan ini menyebabkan pemerintah sulit mengkoordinasi pemerintahan yang ada di daerah. Untuk memudahkan pengaturan atau penataan pemerintahan maka diperlukan adanya berbagai suatu 
sistem pemerintahan yang dapat berjalan secara efisien dan mandiri tetapi tetap dibawah pengawasan dari pemerintah pusat. Di era reformasi ini sangat dibutuhkan sistem pemerintahan yang memungkinkan cepatnya penyaluran aspirasi rakyat di daerah, namun itu juga tetap berada di bawah pengawasan pemerintah pusat, sehingga seluruh kebijakan pemerintah daerah senantiasa mencerminkan cita-cita negara. Berkenaan dengan hal tersebut maka lahirlah otonomi daerah bagi setiap daerah di Indonesia dan Otonomi Khusus bagi beberapa Daerah.

Munculnya otonomi daerah menyebabkan terjadinya pergeseran paradigma dari sistem pemerintahan yang bercorak sentralisasi mengarah kepada sistem pemerintahan yang desentralisasi, yaitu dengan memberikan keleluasaan kepada daerah dalam mewujudkan daerah otonom yang luas dan bertanggung jawab, untuk mengatur dan mengurus kepentingan masyarakat setempat sesuai kondisi dan potensi wilayahnya. Pemberian otonomi kepada daerah pada dasarnya bertujuan meningkatkan daya guna dan hasil guna penyelenggaraan pemerintah daerah, terutama dalam pelaksanakan pembangunan dan pelayanan terhadap masyarakat serta untuk meningkatkan pembinaan kesatuan politik dan kesatuan bangsa. Berdasarkan Undang - Undang Republik Indonesia Nomor 2 Tahun 2015 tentang Pemerintahan Daerah, otonomi yang seluas - luasnya bagi pemerintah Daerah merupakan peluang dan sekaligus tantangan. Peluang disini bagi pemerintahan daerah yang memiliki potensi sumber daya alam yang memadai untuk mengelola sendiri potensi tersebut, sedangkan bagi pemerintah daerah yang mempunyai sumber daya alam yang kurang memadai justru merupakan tantangan. Melaksanakan amanat dari Otonomi Daerah dan Otonomi Khusus bagi Propinsi Papua Barat, maka pemerintah daerah raja ampat mengembangkan berbagai sumber daya alam yang ada guna kesejahteraan masyarakat, dengan memaksimalisasi seluruh sumber daya alam yang berada di laut. Dalam memaksimalisasikan sumber daya laut, maka pemerintah daerah raja ampat menggandeng lembaga-lembaga adat dan masyarakat untuk menjaga kelestarian bioata laut khususnya terumbu karang yang selama ini di jadikan aikon pariwisata kabupaten raja ampat. Pariwisata merupakan sumber penghasilan daerah raja ampat dalam sektor jasa, oleh karena itu pemerintah daerah raja ampat harus berperan penting dalam menjaga kawasan pariwisata agar dapat bersaing dengan daerah lain yang ada di wilayah Indonesia.

Keunikan raja ampat terhadap pesona pariwisatanya masih sangat alami sehingga daya tarik orang asing yang melancong di daerah raja ampat dapat dinikmati dengan baik apalagi 
masyarakatnya yang santun terhadap para turis menambah daya tarik para pelancong di raja ampat. Kenyamanan dalam menikmati keunikan alam yang sangat eksotis ini, tidak lepas dari sikap masyarakat lokal di Kabupaten Raja Ampat dalam peningkatan pariwisata, maka dari itu pemerintah derah bersama lembaga adat dapat mensosialisasikan manfaat dan kegunaan pengembangan pariwisata terhadap masyarakat agar masyarakat paham dan mengerti bahwa pariwisata merupakan aset daerah yang harus ditingkatkan dan dijaga sebaik mungkin. Semakin banyaknya turis melancong ke daerah raja ampat maka pertumbuhan ekonomi akan semakin baik berdasarkan perputaran ekonomi yang bersumber dari para turis lokal dan domestik.

Kedatangan pelancong ke Kabupaten Raja Ampat disebabkan alam laut yang begitu mempesona, dengan jenis ikan dan terumbu karang yang begitu indah sehingga sangata menyegarkan mata. Namun kondisi ini berubah ketika salah satu tempat wisata laut di Pulau Mios Mansuar Kabupaten Raja Ampat di hamtam Kapal Inggris MV Caledonian Sky yang menyebabkan hancurnya terumbu karang seluas 1.600 M2 . Menindaklanjuti pemerintah Kabupaten melakukan berbagai upaya guna memulihkan kembali terumbu karang yang telah rusak, dan juga meminta pertanggungjawaban dari perusak terumbu karang tersebut. hal ini sebagai bentuk tanggungjawab pemerintah daerah raja ampat dalam menjaga kelestarian kawasan laut, dan menindak setiap orang yang dengan sengaja merusak ekosistem laut yang telah diakui sebagai salah satu harta warisan dunia.

Berikut ini hasil wawancara peneliti dengan narasumber penelitian

"Rusaknya terumbu karang di wilayah Raja Ampat Papua Barat kami pemerintah daerah terus menjalin kerjasama dengan kelembaga legislative (DPRD) beserta lembaga adat untuk menyuarakan sanksi hukum terhadap pelaku pengrusakan terumbu karang Kemudian kami sebagi pemerintah daerah berencana melakukan langkah hukum menuntut ganti rugi, hukum pidana pun berupa penahanan layak diterapkan terhadap Nahkoda Kapten pada Kapal Pesiar asal Inggris MV Caledonia Sky. Adapun kami pihak pemerintah daerah tetap akan mengawal kasus ini sampai tuntas supaya bentuk wujud perhatian pemerintah daerah terhadap terumbu karang diraja ampat karena terumbu karang merupakan asset besar dalam pariwisata laut raja ampat bahkan sudah menjadi trend didunia saat ini”.

(Wawancara peneliti dengan Bapak Muhliat Mayalibit, S.H., Kepala Bagian Hukum Pemerintah Kabupaten Raja Ampat, di Kantor Bupati Kabupaten Raja Ampat.) 
Selanjutnya wawancara peneliti dengan narasumber penelitian.

"Kami pihak pemerintah daerah meminta kepada aparatur penegak hukum mestinya melakukan tindakan tegas sekalipun terhadap warga asing. Hukum pidana berlaku di Indonesia berlaku pula terhadap warga asing yang melanggar hukum di wilayah Negara Kesatuan Republik Indonesia.Karena Kapal Pesiar asal Inggris Caledonia Sky masuk ke perairan dangkal seharusnya sudah dapat diantisipasi oleh kapten kapal tersebut.Hal ini yang menjadikan kami pihak pemerintah daerah agar pelaku pengrusakan terumbu karang diraja ampat menggati rugi terhadap perbuatan yang mereka lakukan oleh sebab itu, kami pemerintah daerah meminta kepada pemerintah pusat untuk memberikan pencekalan terhadap kapten kapal MV Caledonia Sky dikedutaan Inggris di Jakarta, dan meminta ganti rugi atas kerusakan tersebut sebesar Rp. 6.000.000.000.000 (enam trilyun rupiah)".

(Wawancara peneliti dengan Bapak Yusdi Lamatengo, S.Pi., M.Si. Kepala Dinas Parawisata Pemerintah Kabupaten Raja Ampat, di Kantor Bupati Kabupaten Raja Ampat)

Kemudian hasil wawancara peneliti dengan narasumber penelitian.

"Permintaan kami sebagai pemerintah daerah untuk pemerintah Republik Indonesia agar membantu menuntut ganti rugi dan menindak kapal pesiar MV Caledonian Sky yang merusak 1.600 meter persegi terumbu karang di Raja Ampat, Papua, pada tanggal 4 Maret 2017 lalu. Karena terumbu karang merupakan aset yang harus dilindungi dan dijaga, sebab pertumbuhan terumbu karang dalam jangka 1 (Satu) tahun hanya tumbuh $1 \mathrm{~cm}$. Oleh sebab itu, kami pemerintah daerah dalam persoalan ini, menjadikan pengalaman yang tidak pernah dilupakan oleh pemerintah daerah agar kedepannya tidak terulang kembali kerusakan terumbu karang”.

(Wawancara peneliti dengan Ibu Sarahia Bahale, Anggota DPRD Kabupaten Raja Ampat Partai DEMOKRAT, di DPRD Kabupaten Raja Ampat).

Berdasarkan hasil wawancara peneliti dengan narasumber penelitian di atas, maka diketahui bahwa Tanggungjawab Pemerintah Daerah Kabupaten Raja dalam Penyelesaian Kerusakan Terumbu Karang ialah melakukan laporan pada Duta Besar Negara Inggris di Jakarta dan juga menyampaikan permasalahan tersebut pada Menteri Kelautan di Jakarta. Laporan tuntutan terhadap kerusakan tersebut berakibat pada dicekalnya kapten kapal dan selanjutnya menuntut ganti rugi atas hancurnya terumbu karang tersebut sebesar Rp. 
6.000.000.000.000 (enam trilyun rupiah). Rusaknya terumbu karang yang diakibatkan oleh kapal pesiar MV Caledonian Sky milik pemerintah inggris menjadi perhatian serius dari pemerintah indonesia, mengingat kekayaan alam laut Kabupaten Raja Ampat merupakan warisan peninggalan dunia yang telah di akui oleh negara-negara di dunia. Disisi lain proses tumbuhnya terumbu karang memakan waktu ratusan tahun, sehingga kerusakan terumbu karang tersebut sangat berakibat fatal terhadap kehidupan laut, dan kehidupan para nelayan yang berdomisili di Pulau Mios Mansuar tempat rusaknya terumbu karang tersebut.

Melihat pentingnya kehidupan terumbu karang terhadap ekosistem laut, dan juga dibutuhkan waktu yang lama untuk melakukan perbaikan terhadap kerusakan yang terjadi sehingga kondisi dapat seperti semula, maka sudah tentu penyelesaian perkara dalam kerusakan terumbu karang di Pulau Mios Mansuar harus diterapkan berbagai hukum, sehingga seimbang dengan akibat yang ditimbulkan. Bertolak dari pemikiran ini, maka peneliti melakukan tanya jawab pada 55 (lima puluh lima) Orang masyarakat yang bermukim di pulau Mios Mansuar atau Responden Penelitian yang untuk menegetahui metode penyelesaian yang dilakukan oleh Pemerintah Kabupaten Raja Ampat sebagai bentuk tanggungjawab dalam menindaklanjuti permaslahan yang terjadi. Adapun rumus perhitungan yang peneliti gunakan untuk mengukur hal tersebut ialah sebagai berikut :

\section{Gambar I}

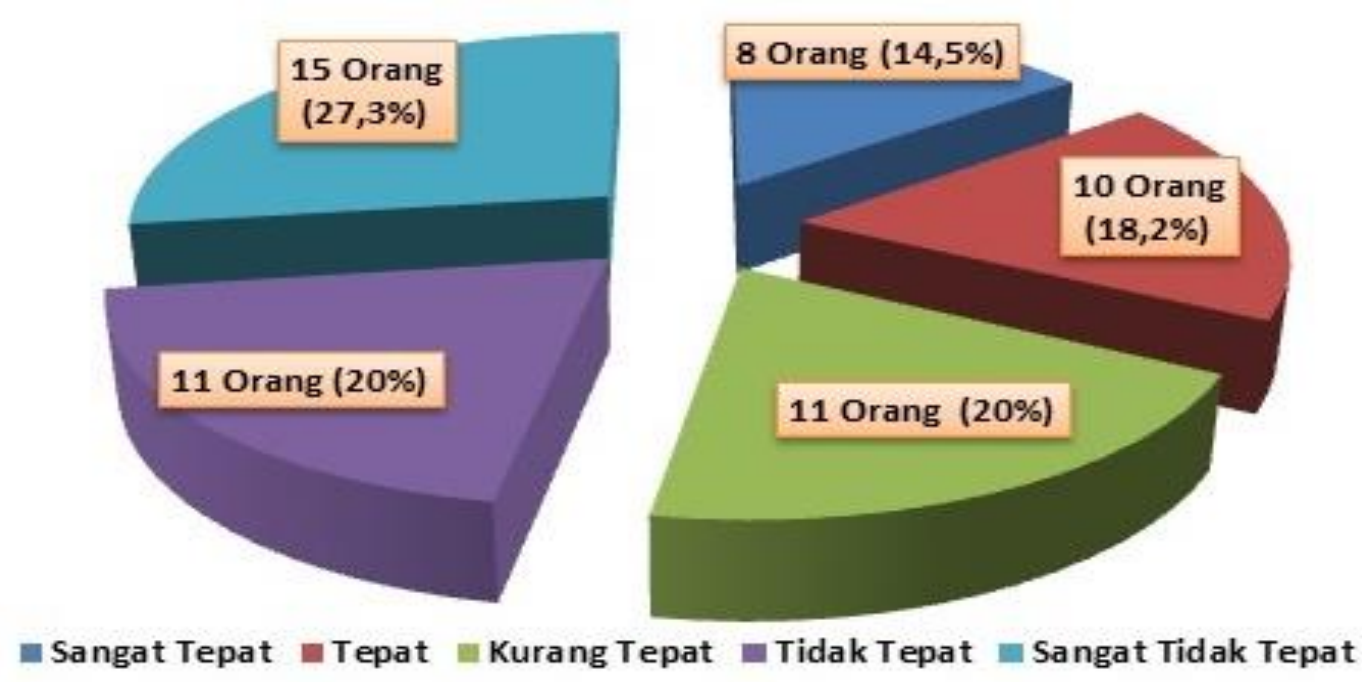

Tangapan 55 (Lima Puluh Lima) Orang Masyarakat Pulau Mios Mansuar (Responden

Penelitian) Terhadap Pemberian Sanksi Ganti Rugi sebagai bentuk penyelesaian kerusakan terumbu karang yang dilkukan oleh Kapal MV Caledonian Sky 
Sumber Data : Hasil Olahan Data Peneliti dalam Penelitian.

\section{Kendala Dalam Penyelesaian Kerusakan Terumbu Karang Di Kabupaten Raja Ampat.}

Negara Indonesia adalah negara berdasarkan hukum. Dalam Undang-Undang Dasar Negara Repblik Indonesa Tahun 1945, telah menegaskan dengan jelas bahwa Negara Republik Indonesia berdasarkan atas hukum (rechtstaat), tidak berdasarkan kekuasaan belaka (machtstaat). Hukum menetapkan apa yang harus dilakukan atau apa yang boleh serta yang dilarang. Sasaran hukum yang hendak dituju bukan saja orang yang nyata-nyata berbuat melawan hukum melainkan perbuatan hukum yang mungkin akan terjadi dan kepada alat pelengkap negara untuk bertindak menurut hukum. Sistem bekerjanya hukum yang demikian itu merupakan salah satu bentuk penegakan hukum. Penegakan hukum pada hakikatnya merupakan penegakan ide-ide atau konsep-konsep serta usaha untuk mewujudkan ide-ide dari harapan masyarakat untuk menjadi kenyataan. Penegakan hukum diartikan sebagai suatu proses dilakukannya upaya tegaknya atau berfungsinya norma-norma hukum secara nyata sebagai pedoman berperilaku. Penegakan hukum ini merupakan upaya aparatur penegak hukum untuk menjamin dan memastikan tegaknya hukum.

Penegakan hukum yang saat ini perlu dilaksanakan adalah penegakan hukum dalam bidang Kelautan. Perkembangan teknologi dalam bidang pembangunan menyebabkan peningkatan pergerakan manusia yang tidak hanya dalam lingkup domestik tetapi juga internasional. Di Indonesia peningkatan arus lalu lintas orang dengan kapal laut masuk dan keluar Indonesia itu disebakan karena posisi Indonesia yang strategis dan juga karena potensi sumber daya alam dan sumber daya manusia yang ada. Peningkatan arus transportasi laut di Indonesia ini dapat memberi dampak positif dan dampak negatif. Dampak postitif antara lain seperti modernisasi masyarakat serta mendorong pertumbuhan ekonomi negara. Sedangkan dampak negatif adalah ketika arus transportasi laut kapal ini dilakukan dengan pola illegal maka akan mendorong meningkatnya perkembangan kejahatan seperti imigran gelap, penyelundupan orang, perdagangan anak dan wanita yang berdimensi internasional dan juga sindikat-sindikat narkotika, terorisme, pencucian uang dan lain-lain.

Dalam penegakan hukum terhadap orang dan perbuatan yang terjadi di suatu negara hukum internasional memberikan yurisdiksi pada negara tersebut. Hal ini berarti penegakan hukum terhadap lalu lintas orang dan perbuatannya ditentukan oleh hukum yang ada di negara itu. Pengaturan terhadap lalu lintas antar negara yang menyangkut kapal asing di suatu wilayah 
negara, adalah berkaitan dengan aspek keimigrasian yang berlaku disuatu negara yang bersifat universal maupun kekhususan masing-masing negara sesuai dengan nilai-nilai dan kebutuhan negara. Di Indonesia untuk menjamin kemanfaatan dan melindungi berbagai kepentingan nasional maka perlu ditetapkan suatu prinsip, tata pengawasan tata pelayananan atas masuk dan keluar kapal asing beserta orang ke dan dari wilayah Indonesia yang sesuai dengan nilainilai Pancasila dan Undang-Undang Dasar Negara Repblik Indonesa Tahun 1945. Berdasarkan landasan inilah dibentuk Undang-Undang Republik Indonesia Nomor 6 Tahun 2011 tentang Keimigrasian.

Terhadap warga negara asing yang masuk dan keluar wilayah Indonesia, pelayanan dan pengawasan dibidang keimigrasian dilaksanakan berdasarkan prinsip yang bersifat selektif. Berdasarkan prinsip ini, hanya orang-orang asing yang dapat memberikan mamfaat bagi kesejahteraan rakyat, bangsa dan negara Republik Indonesia serta tidak membahayakan keamanan dan ketertiban serta tidak bermusuhan baik terhadap rakyat maupun negara kesatuan Republik Indonesia, dan tidak melakukan pengerusakan terhadap hal-hal yang dilindungi oleh negara dengan Undang-Undang yang diizinkan masuk atau keluar wilayah Indonesia. Bertolak dari hal ini, maka pertanggungjawaban hukum harus di berikan oleh warga asing yang karena kelalianya menahkodai kapal pesiar Inggris MV Caledonian Sky Kapten Keith Michael Taylor warga negara Inggris dengan membawa 102 turis dan 79 ABK, sehingga menyebabkan kerusakan terumbu karang seluas 1.600 M2di Pulau Mios Mansuar Kabupaten Raja Ampat, yang merupakan salah satu wilayah di Negara Kesatuan Republik Indonesia. Berangkat dari akibat yang timbul, maka seharusnya telah ada langkah hukum guna menyelesaikan permaslahan ini, namun mirisnya hingga sampai saat ini belum ada tanda-tanda keseriusan dari pemerintah Inggris dalam menyelesaikan pelanggaran hukum yang dilakukan oleh warga negaranya tersebut.

Berikut ini hasil wawancara peneliti dengan narasumber penelitian :

"Kami telah melakukan berbagai upaya untuk meminta pertanggungjawaban hukum terhadap kerusakan terumbu karang di Kabupaten Raja Ampat pada Duta Besar Inggris di Jakarta. Pertemuan itu ditemani oeh menteri oleh Menteri Kelautan Ibu Susi. Selanjutnya masalah ini kami serahkan pada pihak pemerintah pusat untuk mengawal atau langsung berkomunikasi dengan pemerintah Inggris. Terkait tuntutan yang diminta oleh masyarakat juga sudah kami sampaikan dan sampai saat ini Bapak Bupati intens berkomunikasi dengan Ibu menteri, 
kabarnya menunggu team dari pemerintah Inggris untuk datang melihat secara langsung lokasi rusaknya terumbu karang, dan setelah itu baru dapat diselesaikan tuntutan ganti rugi tersebut".

(Wawancara peneliti dengan Bapak Muhliat Mayalibit, S.H., Kepala Bagian Hukum Pemerintah Kabupaten Raja Ampat, di Kantor Bupati Kabupaten Raja Ampat)

Kemudian hasil wawancara peneliti denga narasumber penelitian :

"Kendala yang terjadi dalam penyelesaian kerusakan terumbu karang yaitu belum tibanya perwakilan pemerintah inggris yang datang untuk melihat lokasi rusaknya terumbu karang di Kabupaten Raja Ampat. Terkait tentang besarnya tuntutan ganti rugi telah disepakati bahwa akan di bayarkan, hanya saja harus ada kroscek tempat kejadian dahulu. Informasi yang kami terima dari Bapak Bupati, pihak Inggris dalam bulan maret 2018 sudah tiba di Sorong, sekaligus akan melakukan penanaman terumbu karang di tempat yang rusak. Saat ini kami hanya bisa bersabar saja, diserahkan semua pada pemerintah indonesia yang akan menindaklanjuti, mengigat ini permasalahan antar dua negara, jadi ada mekanisme yang harus dilakukan sebelum pembayaran gantu rugi diserahkan".

(Wawancara peneliti dengan Bapak Yusdi Lamatengo, S.Pi., M.Si. Kepala Dinas Parawisata Pemerintah Kabupaten Raja Ampat, di Kantor Bupati Kabupaten Raja Ampat)

Selanjutnya hasil wawancara peneliti denga narasumber penelitian :

"Permaslahan Rusaknya terumbu karang yang terjadi di Kabupaten Raja Ampat ini merupakan tanggungjawab dari pemerintah indonesia, bukanlah permasalahan Raja Ampat saja, sebab yang melakukan kerusakan terhadap terumbu karang ini adalah warga negara inggris. Adapun keterlambatan yang terjadi dalam ganti rugi disebabkan pemerintah Inggris belum datang meninjau secara langsung terumbu karang yang rusak saja. Permaslahan rusaknya terumbu karang ini bukan sekedar permasalahan nasional tetapi permasalahan internasional, sebab Kekayaan bahari Kabupaten Raja Ampat telah dinobatkan oleh UNESCO sebagai salah satu warisan dari kekayaan dunia. Untuk itu dapat dipastikan bahwa inggris akan membayar ganti rugi, sebab kalau tidak akan menjadi sorotan Dunia dan akan di kecam oleh PBB”.

(Wawancara peneliti dengan Ibu Sarahia Bahale, Anggota DPRD Kabupaten Raja Ampat Partai DEMOKRAT, di DPRD Kabupaten Raja Ampat) 
Berdasarkan hasil wawancara peneliti dengan narasumber penelitian di atas, maka diketahui bahwa Kendala Dalam Penyelesaian Kerusakan Terumbu Karang Di Kabupaten Raja Ampat yaitu disebabkan karena pemerintah Inggris belum melakukan peninjauan terhadap lokasi kerusakan terumbu karang di Kabupaten Raja Ampat, proses ini direncanakan akan dilaksanakan pada bulan maret 2018. Permasalah rusaknya terumbu karang ini ialah permaslahan antar negara sehingga proses penyelesaiannya di atur oleh pemerintah pusat, sementara pemerintah daerah Kabupaten Raja Ampat mendengar tindak lanjut masalah yang telah dilaporkannya tersebut melalui Menteri Kelautan. Setelah dilakukan peninjauan lokasi kerusakan, maka pemerintah Inggris akan melaksanakan pembayaran ganti rugi yang telah di tuntut, dan besaran ganti rugi telah disepakati nilainya oleh Pemerintah Inggris.

\section{SIMPULAN}

Dari hasil penelitian terhadap tangungjawab Pemerintah Kabupaten Raja Ampat terhadap Kerusakan Terumbu Karang yang telah di uraikan diatas tersebut peneliti mendeskripsikan secara analisis dengan mengelola data yang di peroleh di lapangan dari penelitian responden atau narasumber dan beberapa informasi lainnya, maka dapat di simpulkan sebagai berikut :

Bahwa Tanggung jawab pemerintah daerah Kabupaten Raja Ampat dalam penyelesaian kerusakan terumbu karang, yaitu meminta ganti rugi atas kerusakan terumbu karang yang dilakukan oleh Kapal Pesiar asal Negara Inggris seluas 1.600 M2 yakni sebanyak Rp. 6.000.000.000.000 (enam trilyun rupiah), yang disampaikan langsung oleh pemerintah Kabupaten Raja Ampat kepada Kedutaan Besar Inggris di Indonesia. Proses ganti rugi tersebut difasilitasi oleh Pemerintah Indonesi. Tindakan lainyang dilakukan pemerintah Kabupaten Raja Ampat ialah melakukan pengembangan ulang terumbu karang yang telah rusak dengan menanam kembali terumbu karang di perairan Wisata Mansuar Distrik Misos Mansar Kabupaten Raja Ampat, atau tepat kerusakan terumbu karang oleh Kapal MV Kaledonian Sky Milik Pemerintah Inggris yang berwisata di Pulau Mansuar.

Bahwa kendala dalam penyelesaian terhadap kerusakan terumbu karang di Kabupaten Raja Ampat, yaitu belum ditinjauannya lokasi kerusakan tanah oleh pemerintah Inggris sebagai syarat terjadinya ganti rugi, kerusakan terumbu karang di Pulau Mios Mansuar dilakukan oleh warga negara yang berasal dari Inggris sehingga indonesia masih sangat berhati-hati untuk bertindak, adanya hubungan kerjasama dibidang ekonomi antara indonesia 
yang menyebabkan ketergantungan terhadap pemerintahan inggris sehingga pembayaran ganti rugi yang diminta oleh pemerintah Kabupaten Raja Ampat sampai saat ini belum dapat terealisasi.

\section{DAFTAR PUSTAKA}

Souter, DW dan O. Linden. 2000. The health and future of coral reef systems. Ocean \& Coastal Management 43: 657 - 688.

Zhiyong F, Sheng Z. 2009. Research on psychological carrying capacity of tourism destination. Chinese Journal of Population 7 (1) : 47-50.

Hondari Nawawi, 2007. “Metode Penelitian Ilmiah". Penerbit Airlangga Perss, Jakarta.

Suharsini Ari Kunto, 2010. "Prosedur Penelitian Suatu Pendekatan Praktek". Penerbit RinekaCipta, Jakarta.

Suharsini Ari Kunto, 2010. "Metode Penelitian Ilmiah". Penerbit Rineka Cipta, Jakarta.

Hak-Hak Daerah Menurut UU No 12 Tahun 2008 Tentang Pemerintah Daerah. Perubahan Atas UU No.32 Tahun 2004 Tentang Pemerintahan Daerah.

Undang - Undang Nomor 22 Tahun 1999 Tentang Pemerintahan Daerah.

UUD Negara Republik Indonesia Tahun 1945 Dalam Penjelasan UU Nomor 23 Tahun 2014Tentang Pemerintahan Daerah

Undang-Undang No.32 Tahun 2009 Tentang Perlindungan Dan Pengelolaan Lingkungan Hidup.

Undang-Undang Nomor 45 Tahun 2009 Tentang Perikanan.

Undang-Undang No. 1 Tahun 2014 Tentang Perubahan Atas Undang-Undang No. 27 Tahun 2007Tentang Pengelolaan Wilaya Pesisir Dan Pulau-Pulau Kecil.

Undang-Undang No. 31 Tahun 2004 Jo Undang-Undang No. 45 Tahun 2009.

Undang-Undang Perlindungan Dan Pengelolaan Lingkungan Hidup (UUPPLH) No. 32 Tahun2009 Menggantikan Undang-Undang Pengelolaan Lingkungan Hidup (UUPLH) Tahun 1997.

Undang-Undang No 32 Tahun 2009, Landasan Filosofi Tentang Konsep Pembangunan Berkelanjutan Dan Berwawasan Lingkungan. 